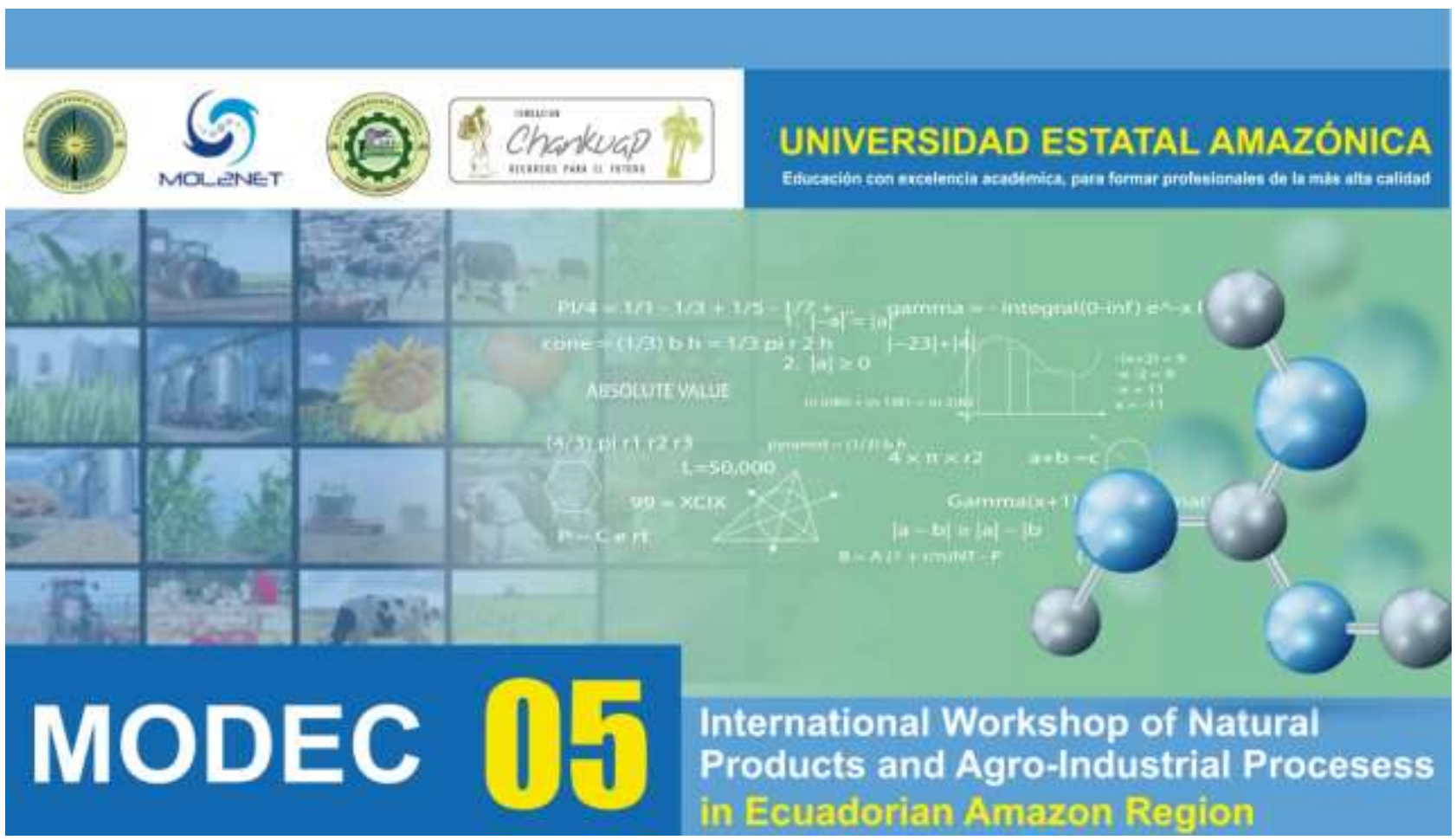

\title{
MODEC05-2020, International Workshop on the Natural Products and Agro-Industrial Processes in Ecuadorian Amazon region
}

Chairperson: Amaury Pérez Martínez, amperez@uea.edu.ec, Universidad Estatal Amazónica, Ecuador Oscar Miguel Rivera-Borroto,omrborroto@gmail.com, Gerardo M. Casañola-Martín, gmaikelc@gmail.com, Karel Dieguez Santana, kdieguez@uea.edu.ec, Universidad Estatal Amazónica, Ecuador Workshop introductory paper signed by the chairperson and some comm. founders on behalf of all the committee.

Abstract: Welcome to the MODEC2020 workshop. This is Amazon State University's (UEA) FIFTH workshop (30 Jan 2020-30 Jan 2021), devoted to the promotion and application of the Multidisciplinary Sciences to the development of natural products and agro-industrial processes in Ecuadorian Amazon regions. This includes the application of Information and Communications Technologies (ICTs) for data analysis and computational model including the fields of Agro-industrial Engineering, Chemistry, Chemical Engineering, Biotechnology, Veterinary Medicine, and/or Environmental Sciences, etc. We invite you to visit the official web of the workshop: https://mol2net-06.sciforum.net/

This workshop runs online. The online workshop is powered by the SciForum platform of MDPI, hosted by the MOL2NET conference, International Conference on Interdisciplinary Sciences. Please, contact the workshop chairmen for further details. Paper submission is already open and the publication of papers for conference purposes in SciForum platform is free of cost.

Publications are expected to be short papers consisting of 1-3 pages. Be aware that the submission is a two step process. First you must register and submit a tentative title, authors list and abstract. Next, you need to submit your full publication upon acceptance of the abstract by the committee. Full publications will be published online, free of charge, with doi number as soon as possible after acceptance. If you are planning to submit a publication, please use the following template, MODEC Template. Click on the following link to register and/or submit your communication Sumit to MODEC here.

All submitted papers should fall under one of the following categories:

- Computational chemistry, Cheminformatics, Bioinformatics and Mathematical modeling

- Organic and Functional Foods

- BioTrade: Natural Products of the Amazon 
- Production Systems with Agro-business and Forestry purposes or biomass for energy purposes Environmental Impacts

- Agro-industrial Development Processes

All summaries should be sent no later than October 1, 2020. The acceptance of a publication will be given October 15, 2020 and completed papers need to be submitted by November 1, 2020. Final acceptance of the finished paper will be given on November 15, 2020 and papers will be published on November 30, 2020.

\section{Chairperson}

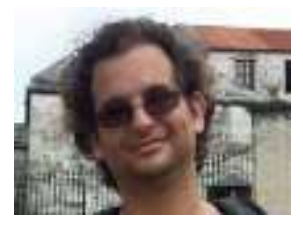

Amaury Pérez Martínez received his Bs. in Chemical Engineering in 2002, his MSc degree in Chemical Engineering Processes and Analysis in 2007, and his PhD degree in Chemical Engineering in 2013. He has worked in the development of new technology in the Chemical Industry. Currently, he is an Aggregate Professor of Agro industrial Engineering at Amazon State University in Puyo, Ecuador. His research interests include philosophy of process design, simulation, and sustainable development

Institution: Universidad Estatal Amazónica, Ecuador

Email: amperez@uea.edu.ec

\section{Local Chairs}

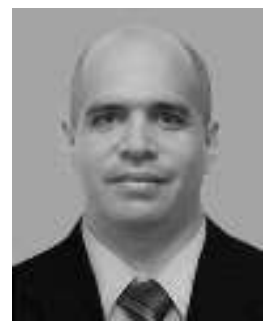

Oscar M. Rivera Borroto (Cuba, 1979), was awarded his BSc. in Chemistry in 2003, his MSc. in Applied Mathematics in 2008, and his PhD. degrees in Mathematics and Chemistry in 2014. His scientific career has been marked by the multidiscipliar contribution of dissimilar fields such as Physical Chemistry, Cheminformatics, and Applied Mathematics toward the common goal of discovering cutting-edge chemical compounds for Pharmacology and other industrial. Also, his academic resume includes a significant professorship activity in countries like Spain, Cuba, and Ecuador. Currently, he works as Fire Supression Systems specialist for the HISD of the city of Houston (Texas, US), and actively collaborates with other academic and corporate organizations.

Email: omrborroto@gmail.com

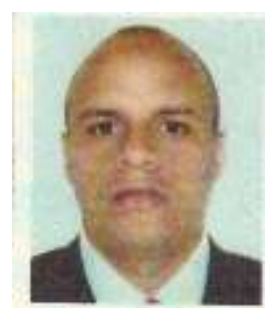

Gerardo M. Casañola-Martín was born in Ciego de Avila, Cuba, in 1979. He received his degree in Chemistry in 2003; and a PhD in Chemical Sciences in 2009 at the Universidad Central de Las Villas, Cuba. He is currently pursuing a PhD in Biomedicine and Pharmacy at Valencia University, Spain. His main research interests are related to the discovery guide of enzyme inhibitors using chem-bio-informatics approaches, drug design and others computer-aided molecular design procedures using different chemometrics, artificial intelligence and machine learning techniques to the application of chemoinformatics among other life sciences to analyze the social impact and related environmental problems.

Email: gcasanola@uea.edu.ec

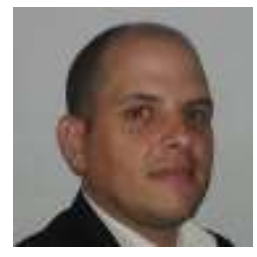

Karel Dieguez Santana obtained his BEng. degree in Chemical Engineering at Central University of "Las Villas", Santa Clara City, Cuba in 2003; MSc. In Environmental Engineering at the Central University of "Las Villas", Santa Clara City, Cuba. He works in the Faculty of Environmental Engineering at the Amazonian State University, Puyo, Ecuador, and his research interests are focused in cleaner technologies in food industries, waste minimization and environmental impact.

Institution: Universidad Estatal Amazónica, Ecuador.

Email:kdieguez@uea.edu.ec 


\section{Advisory Board}

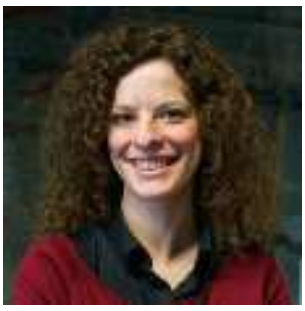

Maria João Matos received her MPharm in Pharmaceutical in 2006, her MSc degree in Organic Chemistry in 2008, her first PhD degree in Pharmaceutical and Chemical Science and Technology in 2010, and her second PhD in Organic Chemistry in 2013. She has worked in Medicinal Chemistry at the University of Porto, and in Chemical Biology at the University of Cambridge. Currently, she is Researcher at the University of Porto and University of Santiago de Compostela. Her research interests include new tools for drug design, discovery and delivery.

Institution: Universidad de Santiago de Compostela, Spain,

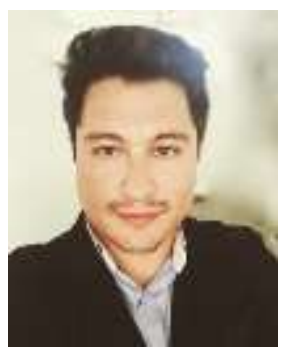

Email: mariajoao.correiapinto@usc.es

Ivan Idrovo González was born in 1984 in Ecuador. He studied in Germany at the University of Bielefeld and lived there for 11 years. He obtained his Bachelor's Degree in English Philology and Social Sciences in 2010. He also holds a Master's Degree in Sociology - Intercultural Studies. He has dedicated a major part of his time to learn and master languages. He speaks Spanish (native language), German (C2), English (C2) Portuguese (C1) and Russian (A1). He worked as translator and interpreter for LKA-61 in Hamburg from 2011 to 2012. He returned to Ecuador in 2013 and worked as an English \& German teacher at Global Exchange - International Language Institute in Quito-Ecuador until 2015. Currently, he teaches English for Biology and Environmental Engineering at Amazon State University in Puyo - Ecuador. He is an international certified English Teacher

Institution: Universidad Estatal Amazónica, Ecuador.

Email: iidrovo@uea.edu.ec

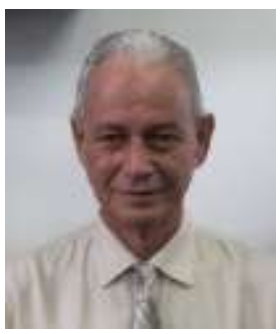

Prof Lopez Trabanco Pedro Jesús has a doctorate in Philological Sciences from the University of Havana, Cuba. He has participated in many scientific international congress and published several books and articles related to teaching and linguistics eg. English al the service of Forestry, and Geology, Dictionary of Forestry, Orchid genera of Cuba, Iconography of Cuban Orchids, Phytonimy of common an botanical names of Ecuadorian and Cuban Orchids, etc. He has collaborated with other international universities in Jamaica, Venezuela, Colombia, Ecuador and Brazil. He has worked in the University of Pinar del Rio. Currently, He has been working in the Universidad Estatal Amazónica Ecuador.

Institution: Universidad Estatal Amazónica, Ecuador

Email: plopez@uea.edu.ec 


\section{Honor Committee}
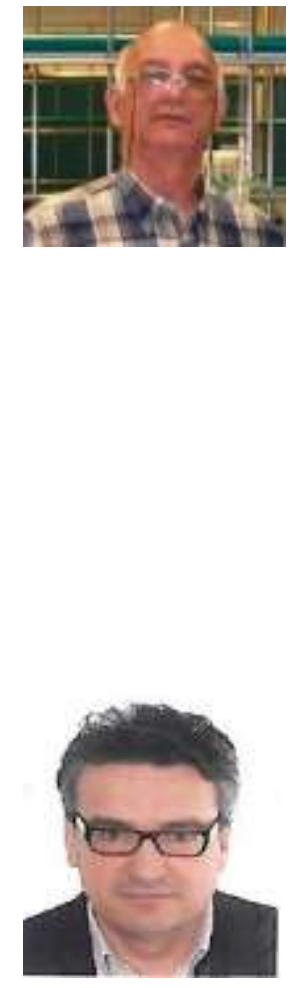

Erenio González Suárez received his Dr.C (PhD) degree in Chemical Engineering from Central the University "Marta Abreu" de Villa Clara in 1982 working in the field of modeling and optimization of technological process and in 1991 has received his Dr.Cs (Second and high level in Cuba) in the thematic the problems of Strategy of process in Chemical Industry. Between 1970 and 1982 has Managing of Projects International Educations, of Investments in the industry and of industrials companies. Since 1982 were Professor and Investigator and Advisory of Vice rector of investigations, managing of groups and Centers of Investigations and of Transfer of Technology center, ace well ace vice rector of Investigations at the same university. There was international coordinator of Projects and Nets of scientific collaboration with countries of Europe and Latin America. There is scientifically leader and investigation about Chemical Industry. He has directed $38 \mathrm{PhD}$ theses. From the year 2006, there is one Member of Merit of the Academy of Science of Cuba and has received the National Reward of Chemical Engineering for the work of their life in the year 2013.

Institution: Universidad Central "Marta Abreu" de Las Villas, Cuba

Email: erenio@uclv.edu.cu

Pedro was born in Valencia in October 1965. He received the Licenciado degree, and the M.S. and the Ph.D. degrees in Theoretical Physics from the Universitat de València (UV), Valencia, Spain in 1988, 1990, and 1992, respectively. He also received the Ph.D. degree in Mathematics from the Universidad Politécnica de Valencia(UPV), Valencia, Spain, in 1997. His research work was performed at UV, UPV, the Joint Institute for Nuclear Research (Russia), the University of Tübingen (Germany) and the Istituto Nazionale di Fisica Nucleare (INFN) in Torino (Italy). He is currently Professor in the Departamento de Matemática Aplicada at UPV.

Nowadays, his research interests include the area of numerical simulation of physical and engineering problems mainly focusing on the analysis of the electromagnetic propagation in optical waveguides and fibre devices (including nonlinear and quantum effects) and on the numerical treatment of heat and mass transfer problems. He is also interested in optimization problems in the field of Synthetic Biology.

Pedro received the distinction of Profesor Invitado (invited professor) at Universidad de Pinar del Río (Cuba) on December, 2002. At the regular meeting of the Colombian Academy of Exact, Physical and Natural Sciences of June 15, 2011, it was approved his designation as a corresponding member. Furthermore, since its establishment on September 30, 2011, he has been a member of the Board of the math-in network (www.math-in.net). Likewise, on October 25, 2012, he received the title of Doctor Honoris Causa from University of Pinar del Rio (Cuba) and on October 17, 2015, he was named an elected fellow of the "Académie Nationale des Sciences, Arts et Lettres du Bénin". Moreover, in Summer 2017, he was awarded the distinction of Profesor Visitante "Ad Honorem" of Universidad del Magdalena (Colombia) and he is Doctor Honoris Causa from Universidad Santander (México) (2018).

Institution: Universidad Politécnica de Valencia, Spain

E-mail: pfernandez@mat.upv.es

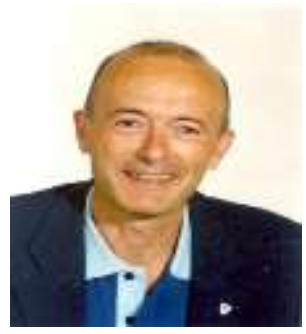

Eugenio Uriarte Villares, PhD in Organic Chemistry in 1983, is Professor of Organic and Medicinal Chemistry since 1989 at the Organic Chemistry Department, Faculty of Pharmacy, University of Santiago de Compostela, Spain. He authored more than 300 publications in international journals and heads an active research group since many years in the organic and medicinal chemistry field with large international collaboration.

Institution: Universidad de Santiago de Compostela

E-mail: eugenio.uriarte@usc.es 


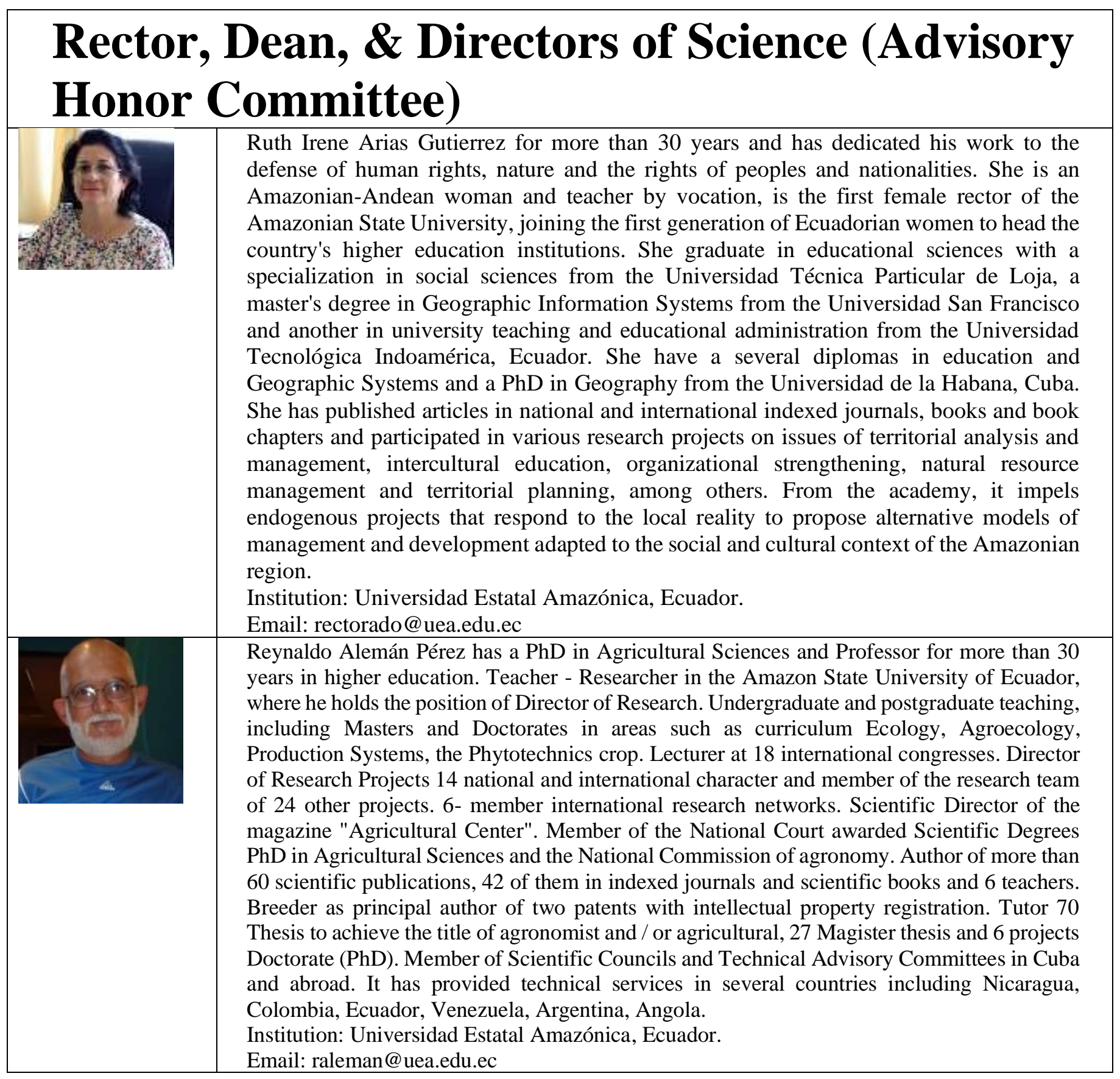




\section{Scientific Committee}

\section{President Scientific Committee (Mathematical modeling, Computational chemistry, Cheminformatics, and Bioinformatics)}

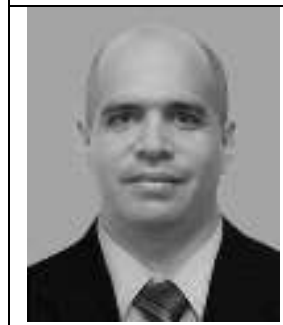

Oscar M. Rivera Borroto (Cuba, 1979), was awarded his BSc. in Chemistry in 2003, his MSc. in Applied Mathematics in 2008, and his PhD. degrees in Mathematics and Chemistry in 2014. His scientific career has been marked by the multidiscipliar contribution of dissimilar fields such as Physical Chemistry, Cheminformatics, and Applied Mathematics toward the common goal of discovering cutting-edge chemical compounds for Pharmacology and other industrial. Also, his academic resume includes a significant professorship activity in countries like Spain, Cuba, and Ecuador. Currently, he works as Fire Supression Systems specialist for the HISD of the city of Houston (Texas, US), and actively collaborates with other academic and corporate organizations.

Email: omrborroto@gmail.com

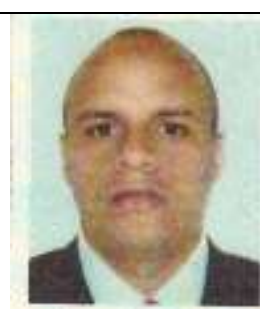

Gerardo M. Casañola-Martín was born in Ciego de Avila, Cuba, in 1979. He received his degree in Chemistry in 2003; and a PhD in Chemical Sciences in 2009 at the Universidad Central de Las Villas, Cuba. He is currently pursuing a $\mathrm{PhD}$ in Biomedicine and Pharmacy at Valencia University, Spain. His main research interests are related to the discovery guide of enzyme inhibitors using chemo-bio-informatics approaches, drug design and others computeraided molecular design procedures using different chemo-metrics, artificial intelligence and machine learning techniques to the application of chemo-informatics among other life sciences to analyze the social impact and related environmental problems.

Email: gmaikelc@gmail.com

\section{President Scientific Committee (Organic and Functional Foods)}

\begin{tabular}{|l|l}
\hline & $\begin{array}{l}\text { Manuel Lazaro Pérez Quintana received his Bs. in Agronomic Engineer in 1985, and his PhD } \\
\text { degree in Veterinary Science in } 2000 \text { in Agrarian University of Havana, Cuba. He has worked } \\
\text { in the development probiotic a functional food. Currently, he is an Aggregate Professor of } \\
\text { Agro industrial Process at Amazonic Stated University in Puyo, Ecuador. His research interests } \\
\text { include of biotechnology, functional foods and natural antioxidant. } \\
\text { Institution: Universidad Estatal Amazónica, Ecuador. } \\
\text { Email: mperez@uea.edu.ec }\end{array}$ \\
\hline
\end{tabular}

\section{President Scientific Committee (BioTrade. Natural Products of the Amazon)}

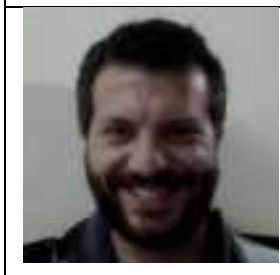

Matteo Radice received his Bs. in Organic Chemistry in 1997, his MSc degree in Science and Technology for the sustainable use of non-traditional biological resources in 2006, and his $\mathrm{PhD}$ degree in Pharmaceutical Science in 2011. Matteo currently works at the School of Earth Sciences, Universidad Estatal Amazónica, Puyo, Ecuador. Matteo focuses his research on Natural Product Chemistry (mainly phytochemistry), Natural Products for Photoprotection and Biotrade (Biocomercio y Bioeconomia). Matteo also collects Review articles concerning the phytochemistry of Amazonian plants.Institution:

Universidad Estatal Amazónica, Ecuador

Email: mradice@uea.edu.ec

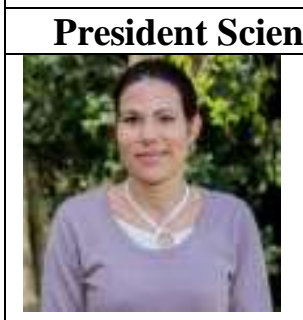

Committee (Environmental impacts)

Yannay Casas Ledón is Chemical Engineer and received her $\mathrm{PhD}$ degree in Applied Biological Science from Ghent University in 2012 under the supervision of Prof Jo Dewulf. Between 2004 and 2014 she worked as full Professor of thermodynamic and unit operations at Chemical Engineering Department of Central university of Marta Abreu de las Villa. From 2014 until currently, she is assistant professor in Environmental Engineering Department of Concepción University, Chile. Her research is mainly oriented to environmental sustainability assessment of cleaner technologies, focusing on the reduction of impact of emissions, making emphasis on the resource intake pattern and on the overall efficiency of the production and consumption chain through life cycle assessment (LCA), exergy analysis, Exergetic Life Cycle Analysis (ELCA), Exergo-environmental and exergo- economic analysis.

Institution: Concepción University, Chile

Email: ycasas@udec.cl

\section{President Scientific Committee (Agroindustrial development processes)}

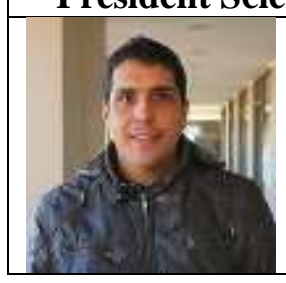

Luis E. Arteaga-Pérez received his Bs. in Chemical Engineering in 2004 at the University Central of Las Villas (UCLV-Cuba). Dr. Arteaga obtained his Dr degree in Technical Sciences $\mathrm{c} / \mathrm{m}$ in Chemical Engineering in 2010 (UCLV-Cuba). He has expertise in Process Synthesis and Applied Catalysis for Sustainable Energy Systems. Currently, Dr. Arteaga is Associate Professor at the Chemical Eng. School in the University of Bio-Bio (Chile) and Main Researcher of Unit for Technological Development at the University of Concepción (Chile). 
At the moment Professor Arteaga leads 5 research projects and participate in 2 international networks, focussed on substituing fossil resources from their current applications by using natural-occurring molecules.

Institution: University of Bio-Bio, Chile

Email: luiseap@gmail.com 


\section{Scientific Committee Members}

\section{Mathematical modeling, Computational chemistry, Cheminformatics, and Bioinformatics}

The application of computational chemistry, cheminformatics, and bioinformatics to the discovery of new bioactive compounds within the Ecuadorian Amazon ecosystem which can contribute to the identification of natural agents with drug-like bioactivity that will serve to relieve the symptoms of socially relevant diseases. These findings have the potential to enhance the health, well-being, and quality of life for the native population. This section is devoted to, but not limited to the following fields/subjects of study: description of new bio compounds and data sets, (quantum) similarity measures, similarity/diversity searching, clustering algorithms, QSAR techniques, validation metrics, the discovery of enzyme inhibitors, proteasome, tyrosine, computer-aided molecular design, lead optimization, artificial intelligence and machine learning, multi-target approaches, QSPR, QSAR, QSTR, applied computer sciences, and applied statistics.

For the mathematical modeling, papers relating to the use of mathematical tools used to obtain or support the presented results will be shared. These purpose of this research is aimed finding natural products in the Amazonian region of Ecuador linked to agro-industrial processes and the related disciplines such as Chemical Engineering, Biotechnology and environmental processes. The modeling process should strengthen the analysis of the experimental processes in order to describe with adequate precision the processes, phenomena, data, etc. The techniques applied may be statistical or nonstatistical consistent with data analysis and computer and communications technologies. The obtained results may be presented in any stage of the model: development, analysis or interpretation.

\section{President}

\begin{tabular}{|c|c|}
\hline \multicolumn{2}{|l|}{ Members } \\
\hline & $\begin{array}{l}\text { Yunierkis Pérez-Castillo obtained his PhD in Science in } 2013 \text { at the "Vrije Universiteit } \\
\text { Brussel", Belgium and currently is a professor at the "Universidad Técnica Particular de Loja", } \\
\text { Ecuador. He has a large experience in researches related to the design, implementation and } \\
\text { application of computational tools to biological, chemical and pharmaceutical problems. He } \\
\text { has published more than } 15 \text { papers in peer- review journals and participated in several } \\
\text { international conferences. His research skills include the application of structure-based drug } \\
\text { design tools such as homology modeling, molecular dynamics, molecular docking and virtual } \\
\text { screening. In addition, he has programming skills and in the application of machine learning } \\
\text { algorithms to ligand-based drug discovery. } \\
\text { Institution: Universidad Técnica Particular de Loja, Ecuador } \\
\text { Email: yperez@ utpl.edu.ec }\end{array}$ \\
\hline & $\begin{array}{l}\text { Liliana Cerda-Mejía received her Bs. in Food Engineering in 2010, her MSc degree in } \\
\text { Molecular Biotechnology in 2012, and her Ph.D. degree in Environmental Microbiology and } \\
\text { Biotechnology in 2016. She has worked in the development of new technology in the Genomics } \\
\text { and Proteomics. Currently, she is a Lecture of Food Engineering at Universidad Técnica de } \\
\text { Ambato in Ambato, Ecuador. Her research interests include protein design, enzymatic } \\
\text { bioremediation processes, and rational drug development } \\
\text { Institution: Universidad Técnica de Ambato, Ecuador. } \\
\text { Email: la.cerda@uta.edu.ec }\end{array}$ \\
\hline & $\begin{array}{l}\text { Viviana Fernanda Quevedo Tumailli received her engineering in computer systems in } 2005 \text {, } \\
\text { her MSc degree in Technologies for management and teaching practice in 2014, and currently } \\
\text { she is studying her PhD degree in Information and Communication Technologies in Coruña, } \\
\text { Spain. She has worked in complex networks. She is an Auxiliary Professor in the Department } \\
\text { of Earth Sciences at Universidad Estatal Amazónica in Puyo, Ecuador. Her research interests } \\
\text { include of graph theory and the complex networks } \\
\text { Institution: Universidad Estatal Amazónica, Ecuador. } \\
\text { Email: vquevedo@uea.edu.ec }\end{array}$ \\
\hline
\end{tabular}




Delfín Bernabé Ortega Tenezaca received his Analyst in Informatic Systems in 2005, his
engineering in computer systems in 2006, his Specialist in Curricular Design by Competences
in 2010, his MSc degree in Magister in University Teaching and Educational Administration
in 2011 and his Magister in Database Management in 2017. Currently, he is studying his PhD
degree in Information and Communication Technologies in Coruña, Spain. He has worked in
PTML and complex networks. He is a Professor in the Department of Leveling at Universidad
Estatal Amazónica in Puyo, Ecuador. He is a Analyst TIC 2 in the information Unit. His
research interests include of graph theory, the complex networks and PTML.
Institution: Universidad Estatal Amazónica, Ecuador.
Email: bortega @uea.edu.ec




\section{Organic and Functional Foods}

Functional foods have been conceptualized by different researchers and institutions from all over the academic and business worlds. The European Council on Food Information defined functional foods as those that are consumed as part of a normal diet, to provide essential nutrients for life such as proteins with essential amino acids, carbohydrates, fats, vitamins and minerals. They also contain biologically active components that offer health benefits as they reduce the risk of chronic degenerative diseases such as diabetes, hypertension, and cancer among others.

The main components of a successful functional food can be summarized in the following categories:

1. Organic food production.

2. Intestinal Micro Flora Balancing including probiotics, prebiotics and synbiotics.

3. Antioxidants and their impact on health.

4. Dietary fiber as part of a healthy diet.

5. The marketing of healthy, organic food.

6. The health benefits of using the Ecuadorian Amazon as a food source. Submissions should pertain to the above mentioned categories.

\section{President}

Manuel Lazaro Pérez Quintana,

\section{Members}

\begin{tabular}{|c|c|}
\hline & $\begin{array}{l}\text { Aldo Hernández Monzón received his PhD degree in Technical Sciences from the Politecnical } \\
\text { Institute José Antonio Echevarria, in Havana Cuba in 1990; the research was in the development } \\
\text { of rheological technics for optimization and control of technological processes applied in semi } \\
\text { hard cheeses, under the supervision of PhD Antonio Díaz -Abreu. From } 1972 \text { up to } 1993 \text { he was } \\
\text { Professor of Food Engineering in the Chemical Engineering Faculty of the same Institute and since } \\
1994 \text { work as professor of Food Science and Technology in the Institute of Pharmacy and Food of } \\
\text { Havana University. He is a member of the Doctoral committee in Food Science and of the Food } \\
\text { Science and Technology Master. The Research work involves the evaluation and development of } \\
\text { functional dairy products and he has directed } 6 \text { PhD theses, and delivered lectures and courses in } \\
\text { universities of Mexico, Colombia and Ecuador } \\
\text { Institution: Havana University, Cuba } \\
\text { Email: aldohm@ifal.uh.cu }\end{array}$ \\
\hline & $\begin{array}{l}\text { Javier Dominguez Brito received his engineering degree in agricultural mechanization in 1996, his } \\
\text { PhD in Mechanization and Agricultural Technology in } 2003 \text {. He has worked on research on the } \\
\text { impact of mechanization on agricultural land, energy in agriculture and the application of organic } \\
\text { amendments for soil recovery. Currently, he is an associate professor of Agricultural Engineering } \\
\text { at the Amazon State University in Puyo, Ecuador. His research interests include Evaluation of the } \\
\text { agricultural behavior of crops in Amazonian conditions, Crops in Hydroponic Systems and } \\
\text { Recovery of degraded soils. } \\
\text { Institution: Universidad Estatal Amazónica, Ecuador } \\
\text { Email: jdominguez@uea.edu.ec }\end{array}$ \\
\hline & $\begin{array}{l}\text { Maria Isabel Viamonte Garces received her university studies in } 1986 \text { in Dra. Medicina } \\
\text { Veterinaria. Her PhD in Veterinary Sciences in } 2010 \text {. He has worked for } 30 \text { years in research in } \\
\text { the management of livestock farms; clinic and reproduction; animal physiology; feeding in cattle, } \\
\text { poultry and pigs. Currently, he is a professor of agricultural studies at the State Amazonian } \\
\text { University, Puyo, and Pastaza, Ecuador. Her research interests include the conservation and } \\
\text { improvement of autochthonous and creole races; feeding alternatives in several species of animals } \\
\text { and the sustainable management of cattle fry. Institution of the Amazon State University. E-mail: } \\
\text { mviamonte@uea.edu.ec Institution: Universidad Estatal Amazónica, Ecuador } \\
\text { Email: mviamontes@uea.edu.ec }\end{array}$ \\
\hline & $\begin{array}{l}\text { Estela Guardado received his Bs. in Pharmaceutical Sciencesg in 1998, her MSc degree in Food } \\
\text { Science and Technology is in 2010. She has worked in the Functional Food and QSAR studies. } \\
\text { Currently, she is an Professor of Food Science at Universidad de Camagüey, in Camagüey, Cuba. } \\
\text { Her research interests include Polyphenols, antioxidants, prooxidant, and Functional Foods. } \\
\text { Institution: Universidad de Camagüey "Ignacio Agramonte Loynaz", Cuba. } \\
\text { Email: estela.guardado@reduc.edu.cu }\end{array}$ \\
\hline
\end{tabular}




\section{BIOTRADE. Natural Products of the Amazon}

BioTrade alludes to collection, production, transformation and commercialization activities of goods and services obtained from native biodiversity in terms of environmental, social and economic sustainability. In 1996, the United Nation Conference on Trade and Development (UNCTAD) launched the "BioTrade Initiative" that has been promoting Biotrade at local level with local farmers and producers. The Amazon basin is strongly involved in Biotrade because of its high biodiversity of natural resources and because of the wide number of transformations in the value chain. Ecuador as well as the other Amazonian countries are a promissory expectation for the "Biotrade Initiative", in light of its high biological resources and related cultural heritage. Some experiences on Biotrade are available and they suggest big opportunities for new incomes for local farmers and producers, as well as for scientific research.

\section{President}

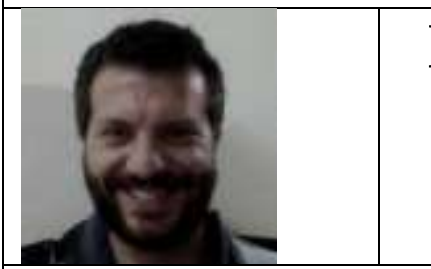

\section{Matteo Radice}

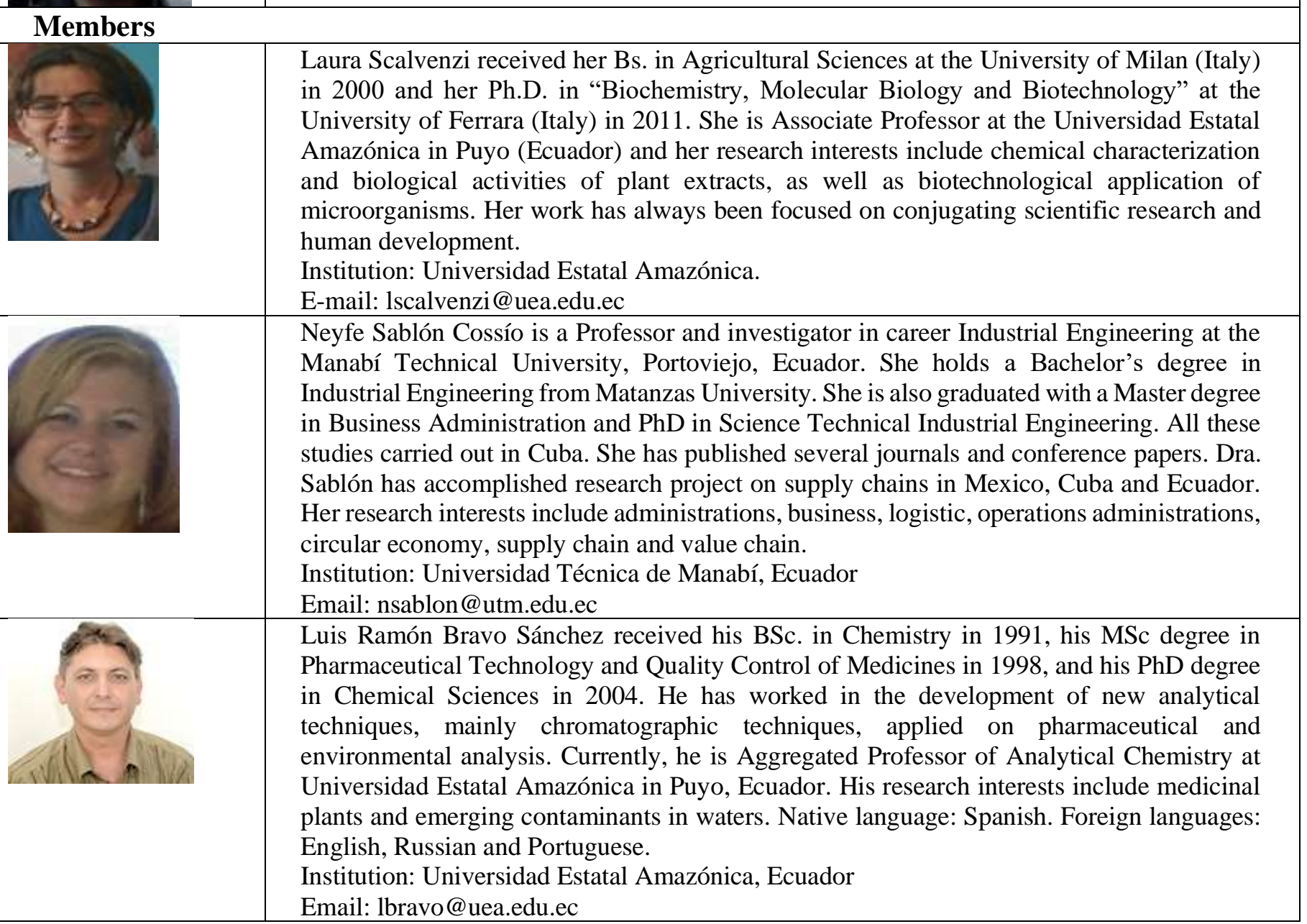




\section{Production systems withagribusiness and forestry purposes. Biomass for energy purposes.}

This workshop pretends to be a meeting point to exchange information about research processes in the use of biomass for renewable energy production in order to foment the development and application of the research activities in the Amazon region in Ecuador. In this context, the workshop tries to cover all aspects related to the use of biomass as a renewable resource, using agro-forest residues to produce clean biofuels.

- $\quad$ Biomass (including waste) recovery and recycling

- $\quad$ Biomass for biofuels (liquid and gaseous)

- $\quad$ Biomass for bio-based chemicals \& products

- Thermochemical conversion and pretreatment of biomass

- $\quad$ Bio-refineries and white biotechnology

- $\quad$ Systems approach: biomass systems analysis, life cycle assessment (LCA), carbon accounting

- Industrial applications and up-scaling

- Biomass policy \& economics

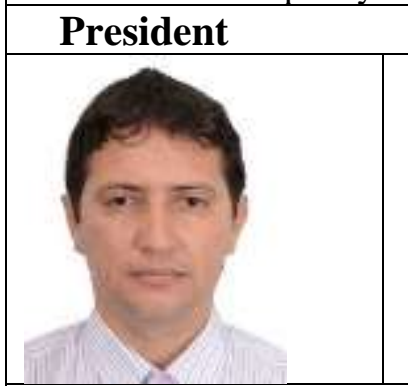

\section{Reinier Abreu Naranjo}

\section{Members}

\begin{tabular}{|l|l|} 
Yasiel Arteaga Crespo received his Bs. in Chemistry in 2002, his MSc degree in Organic \\
Chemistry in 2007, and his PhD degree in Forest Science in 2013. He has worked in the \\
Natural Product area and ecophisiological process in forest plant. Currently, he is an \\
aggregate professor of forest engineering at Universidad Estatal Amazónica in Puyo, \\
Ecuador. His research interests include of photosynthetic nutrient-use efficiency in tropical \\
trees in Ecuadorian Amazon. \\
Institution: Universidad Estatal Amazónica, Ecuador \\
Email: yarteaga@uea.edu.ec
\end{tabular}




\section{Environmental impacts}

This workshop brings together engineers, scientists, researchers, students, managers and other professionals in order to address and discuss emerging environmental issues related to agroindustry and petrochemicals processes, waste management, wastewater treatment and cleaner technologies.

Authors are invited to submit papers from the following areas:

- Evaluation of carbon footprint and water footprint management for existent and new technologies.

- $\quad$ Advances in life cycle assessment and life cycle management of agroindustry and petrochemical processes.

- Improved processes through development and usage of "environmentally friendlier" technologies using agriculture waste.

- $\quad$ Sustainability of agroindustry and petrochemicals processes.

- $\quad$ Agriculture and petrochemical waste management.

- $\quad$ Environmental assessment of wastewater treatment.

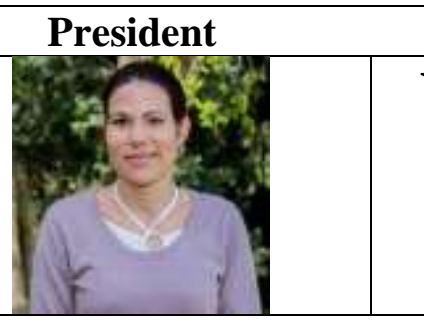

\section{Yannay Casas Ledón}

\section{Members}

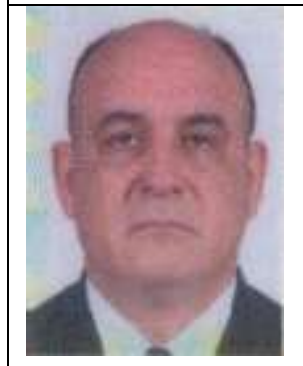

Eugenio Martinez Castellanos. PhD degree in Chemical Engineering from the Universidad Central de la Villas, Cuba. Since 1984, he has been working in the field of wastewater treatment, particular heavy metal contamination.

Between 2000 and 2006, he worked in the industrial sector of petroleum and industrial security.

He was full-time Professor at the University of Camaguey from 1984 to 2000. Since 2006, he has worked in several universities such as "Universidad Olmeca" and "Universidad Politecnica del Golfo de Mexico"

He is a Professor of Discrete Event Simulation and Sustainable Development at the Industrial Engineering Department in the Technological Institute of Comalcalco. His main research interests concern the development of natural and artificial sorbent for the treatment of contaminated wastewater.

He works with simulator ARENA to develop relative models to queuing systems and inventory.

Institution: Instituto Tecnológico Superior de Comalcalco, México

Email: eugenio.martinez@campus.itsc.edu.mx

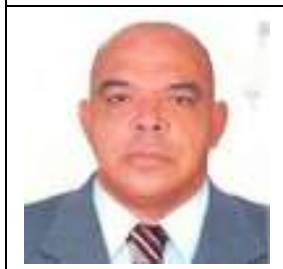

Pablo Angel Galindo Llanes received his PhD degree in chemical engineering from the University of Camagüey "Ignacio Agramonte Loynaz", Cuba in 2008. The topic of his work was process analysis and environmental management. Since 2009, he is a full-time Professor in chemical engineering. His main research interests concern the development of new methodological approaches and their application in the field of process analysis and environmental management. Since 2014, he is vice rector of science, research and postgraduate education in the same university. He is a member of the $\mathrm{PhD}$ examining board on Chemical engineering.

Institution: Universidad de Camagüey "Ignacio Agramonte Loynaz”, Cuba. Email: pablo.galindo@reduc.edu.cu

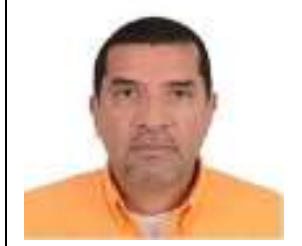

Carlos Alfredo Bravo Medina was Senescyt Postdoctoral Program and Amazon State University, Ecuador for two years. Doctor in Environmental Engineering at the University of Cordoba, Spain. Magister Scientiarum in soil Science, Central University of Venezuela. Agronomy engineer, Romulo Gallegos University, Venezuela. Between 1993 and 2014 he was Titular Professor at the Simon Rodriguez University, Venezuela. Director of Research Center of Agroecology for 8 years. I currently work as a research professor in the Amazon, Ecuador State University and coordinated program management and environmental conservation. Teaching graduate and undergraduate, Masters and Doctorates.

Institution: Universidad Estatal Amazónica, Ecuador Email: cbravo@uea.edu.ec 


\section{Development of agroindustrial processes}

To ensure the alimentary security of the global population demands a development of optimized and wisely-designed agroindustrial processes. This upgrading of existing technologies requires a common effort from the scientific community. The alimentary and technical issues associated to agroindustrial processes in Ecuador's Amazon Region are the main drivers for selecting this place as an ideal forum for the discussion and dissemination of knowledge. Therefore, this section encourages scientists to work on improving productivity, efficiency and sustainability of existing and novel agroindustrial processes to submit their works for an open discussion. Papers concerning the reuse and/or valorization of agroindustrial residues, such as: biochar for soil, water and gas treatment and construction materials are very welcomed. This section will pay special attention to those studies concerning to promote strategies for the development and preservation of indigenous communities from the agroindustrial perspective.

\begin{tabular}{|c|c|}
\hline \multicolumn{2}{|l|}{ President } \\
\hline & Luis E. Arteaga-Pérez \\
\hline \multicolumn{2}{|l|}{ Members } \\
\hline & $\begin{array}{l}\text { Víctor Rodrigo Cerda Mejía received his Bs. in Food Engineering in 2003, his MSc degree } \\
\text { in Mathematical in 2011, and in the current PhD degree candidate in Chemical Engineering. } \\
\text { He has worked in the development of new technology in the Process Industry. Currently, he } \\
\text { is an assistant Professor of AgroIndustrial Engineering at Universidad Estatal Amazónica in } \\
\text { Puyo, Ecuador. His research interests include of process design, simulation and modeling. } \\
\text { Institution: Universidad Estatal Amazónica, Ecuador } \\
\text { Email: vcerda@ @uea.edu.ec }\end{array}$ \\
\hline & $\begin{array}{l}\text { Juan Esteban Miño Valdés was born in Argentina. He is a Chemical Engineer, with emphasis } \\
\text { in Environmental, Quality and Production. He also holds a MSc. Degree in Food } \\
\text { Technology, a Ph.D. in Technical Sciences and a Post Doctorate in Science and Innovation } \\
\text { in the Chemical Industry. Assistant Professor and Researcher in the Faculty of Engineering } \\
\text { at the National University of Misiones, Argentina. Books published: 14. Book chapters } \\
\text { written: } 51 \text { Technical reviews: 14. Journal publications: } \\
\text { Institution: Universidad Nacional de Misiones, Argentina } \\
\text { Email: minio@ fio.unam.edu.ar }\end{array}$ \\
\hline & $\begin{array}{l}\text { Isnel Benítez Cortés. Dean of the Faculty of Applied Sciences. received his Bs. in Chemical } \\
\text { Engineering in } 1993 \text { and his PhD degree in Chemical Engineering in 2009. He has worked } \\
\text { in the development of new technology in the Chemical Industry. Currently, he is the Dean } \\
\text { of Science Aplicated Faculty and Professor of Chemical Engineering at Universidad of } \\
\text { Camaguey, Cuba. His research interests include of process design, simulation and oil } \\
\text { combustion. } \\
\text { Institution: Universidad de Camagüey Ignacio Agramonte Loynaz, Cuba. } \\
\text { Email: isnel.benites@ reduc.edu.cu }\end{array}$ \\
\hline & $\begin{array}{l}\text { Hilda de las Mercedes Oquendo Ferrer received her Bs. in Industrial Engineering in } 1984 \\
\text { and his PhD degree in Chemical Engineering in } 2002 \text {. She has worked in the development } \\
\text { and analysis of process in the Chemical and Agrultural Industry. Currently, she is an Titular } \\
\text { Professor of Industrial Engineering Department and Cordinator of PhD Program in Chemical } \\
\text { Engineering at Camaguey University. Her research interests include analysis of process, } \\
\text { engineering quality and plant layout. } \\
\text { Institution: Universidad de Camaguey Ignacio Agramonte Loynaz, Cuba. } \\
\text { Email: hilda.oquendo@ reduc.edu.cu }\end{array}$ \\
\hline & $\begin{array}{l}\text { Paulina Ulloa Morejón received her bachelor, in Food Engineering in } 2007 \text { and her master's } \\
\text { degree in Agroindustrial Production Management in 2012, she is going to study doctoral } \\
\text { studies in Agricultural Sciences. She has worked in the development of new products in the } \\
\text { food industry. Currently, she is an associate professor of Agroindustrial Engineering at the } \\
\text { Universidad Estatal Amazónica in Puyo, Ecuador. Her research interests include the } \\
\text { development of functional foods. } \\
\text { Institution: Universidad Estatal Amazónica. Ecuador. } \\
\text { Email: julloa@ uea.edu.ec }\end{array}$ \\
\hline
\end{tabular}




\begin{tabular}{l|l|} 
Amaury Pérez Sánchez received his Bs. in Chemical Engineering in 2009. He has worked \\
in a biotechnology plant as a fermentation supervisor. Currently, he is an Instructor Professor \\
at University of Camagüey, and he is pursuing a Master's Degree in Biotechnology. His \\
research interests include simulation of chemical and biotechnological processes, heat and \\
mass transfer equipment design, and techno-economic evaluation/design of chemical plants. \\
Institution: University of Camagüey. Cuba \\
Email: amaury.psanchez@ @ reduc.edu.cu
\end{tabular}

